\title{
PERAN BHABINKAMTIBMAS SERTA MASYARAKAT DALAM UPAYA PENCEGAHAN GANGGUAN KEAMANAN DAN PENYELESAIAN SENGKETA DI KABUPATEN LABUHANBATU
}

\author{
Wahyu Simon Tampubolon \\ Dosen Tetap Fakultas Hukum, Universitas Labuhanbatu, Sumatera Utara \\ (Wahyu.tampubolon@yahoo.com)
}

\begin{abstract}
The Indonesian National Police is directly responsible under the President. The police carry out police duties throughout Indonesia. The police are one of the foremost persons of society, the role of the police at this time is as a guardian of security and order as well as law enforcement officers in society related to criminal law, the police are able to carry out their duties professionally, where their birth originates from the community, according to their needs and desires they. This is done in order to create a situation and conditions that are safe, orderly, serene, and peaceful in social life, which then develops in accordance with developments and changes in state conditions. The National Police, which started from the public side, is now on the side of the state, which has a role to face and control the community itself. Law Number 2 of 2002 concerning the State Police of the Republic of Indonesia, the duties, authorities and rights of the police, in which Article 2 the function of the National Police is to maintain security and public order (kamtibmas).

In accordance with the philosophical foundation of the Unitary State of the Republic of Indonesia is Pancasila which is the basis of our country, especially the fourth principle "Democracy led by Wisdom in Deliberation / Representation". The fourth precept of this Pancasila, requires that the resolution of disputes, conflicts or cases be carried out through deliberation to reach a consensus which is embraced by a family spirit. This means that any dispute, conflict or case that needs to be built through negotiation or peace procedures between the disputing parties to reach a mutual agreement. Initially court mediation tended to be facultative or voluntary (voluntary), but now it leads to imperative or future (mandatory).
\end{abstract}

Keywords: Bhabinkamtibmas, Society, disturbance, dispute resolution

\begin{abstract}
ABSTRAK
Kepolisian Negara Republik Indonesia merupakan institusi yang bertanggung jawab langsung di bawah Presiden. Kepolisian mengemban tugas-tugas kepolisian di seluruh wilayah Indonesia. Kepolisian merupakan salah satu institusi negara yang terdepan penjaga masyarakat, Peran Polisi saat ini adalah sebagai pemelihara Kamtibmas juga sebagai aparat penegak hukum dalam masyarakat yang berkaitan dengan hukum Pidana, hendaknya polisi mampu melaksanakan tugasnya secara profesional, dimana kelahirannya berawal dari masyarakat, sesuai dengan kebutuhan dan keinginan mereka. Hal tersebut dilakukan guna mewujudkan situasi dan kondisi yang aman, tertib, tenteram, dan damai dalam kehidupan bermasyarakat, yang selanjutnya berkembang sesuai dengan perkembangan dan perubahan kondisi negara. Polri yang berawal dari pihak masyarakat kini menjadi berada pada pihak negara yang berperan untuk menghadapi dan mengontrol masyarakat itu sendiri. Undang- Undang Nomor 2 Tahun 2002 tentang Kepolisian Negara Republik Indonesia mengatur tentang kewajiban, tugas, kewenangan dan hak-hak kepolisian, dimana dalam Pasal 2 fungsi Polri adalah menjaga keamanan dan ketertiban masyarakat (kamtibmas).

Sesuai dengan landasan filosofis Negara Kesatuan Republik Indonesia adalah Pancasila yang merupakan dasar negara kita terutama sila keempat "Kerakyatan yang dipimpin oleh Hikmat Kebijaksanaan dalam Permusyawaratan/Perwakilan". Sila keempat dari Pancasila ini diantaranya menghendaki, bahwa upaya penyelesaian sengketa, konflik atau perkara dilakukan melalui musyawarah untuk mencapai mufakat yang diliputi oleh semangat kekeluargaan. Hal ini mengandung arti bahwa setiap sengketa, konflik atau perkara hendaknya diselesaikan melalui prosedur perundingan atau perdamaian di antara pihak yang bersengketa untuk memperoleh kesepakatan
\end{abstract}


bersama. Semula mediasi di pengadilan cenderung bersifat fakultatif atau sukarela (voluntary), tetapi kini mengarah pada sifat imperative atau memaksa (compulsory).

Kata kunci : Bhabinkamtibmas, Masyarakat, pencegahan gangguan, penyelesaian sengketa

\section{PENDAHULUAN}

\subsection{Latarbelakang}

Undang - Undang Nomor 2 Tahun 2002 tentang Kepolisian Negara Republik Indonesia telah diatur dalam Pasal 1 angka 5, yang pada intinya adalah dalam menjaga keamanan dan ketertiban masyarakat serta tercapainya pembangunan nasional, maka perlu adanya kerjasama antara Polri dan masyarakat untuk mencegah, menangkal serta menanggulangi segala bentuk pelanggaran hukum serta tindak pidana yang meresahkan masyarakat atau dapat dikatakan sebagai gangguan kamtibmas dalam kehidupan sosial masyarakat. Dimana peran Polri yang langsung berhubungan dengan masyarakat, Polri dianggap harus mampu bekerjasama dengan masyarakat guna menjaga ketertiban, ketentraman, dan norma yang berlaku dalam lingkungan masyarakat. Hal tersebut karena masyarakat juga mengharapkan norma tersebut dapat dipatuhi. Namun tidak semua masyarakat paham dan mau mematuhi norma yang mereka kehendaki sendiri, sehingga untuk itulah kedudukan Polri sebagai pelaku penegak hukum dapat mendorong terwujudnya kondisi yang aman dan tertib dalam masyarakat.

\section{Dalam Surat Keputusan Kapolri} Nomor 737/X/2005 dimana dalam surat ini berisikan bahwa seluruh anggota Polri diharapkan dapat mendukung penerapan oleh Bhabinkamtibmas (Bhayangkara Pembina Keamanan Dan Ketertiban Masyarakat), dengan cara membangun dan membina kemitraan antara polisi dengan masyarakat yang mengedepankan pada pemecahan masalah yang berkaitan dengan keamanan dan ketertiban masyarakat (kamtibmas). Polri diwujudkan melalui petugas Polmas sedangkan masyarakat diwujudkan melalui mekanisme FKPM (Forum Kemitraan Polisi Masyarakat). Selain itu unsur pemerintah dapat diwujudkan dengan perangkat pemerintah daerah khususnya kepala desa atau lurah. Dimana masing-masing komponen mempunyai peran dalam melaksanakan Polmas melalui Bhabinkamtibmas.

Peran dari Forum Kemitraan Polisi Masyarakat (FKPM) untuk menjaga katimbas yang kondusif di wilayah khususnya di Labuhanbatu dengan cara memberi pendapat dan saran kepada Kepolisian secara timbal balik. Meningkatkan kesadaran dan kepatuhan hukum secara aktif membantu mencegah dan mengatasi tejadinya pelanggaran di wilayah kelurahan atau desa. Inti dari pembentukan Forum Kemitraan Polisi Masyarakat (FKPM) ini adalah untuk membantu tugas Kepolisian melalui polmas dalam membangun katibmas. 
Sehingga hal-hal yang muncul dan tergolong kecil bisa diselesaikan dengan kekeluargaan oleh Forum Kemitraan Polisi Masyarakat (FKPM), tidak harus dibawa ke kantor Polisi di wilayah hukum Polres Labuhanbatu.

\subsection{Rumusan Masalah}

Berdasarkan uraian yang sudah dikemukakan pada latar belakang, maka terdapat beberapa pokok permasalahan yang dapat dirumuskan sebagai berikut :

1. Bagaimana Peran Bhabinkamtibmas dalam menjaga keamanan dan ketertiban serta upaya penyelesaian sengketa melalui musyawarah di Labuhanbatu?

2. Bagaimana peranan masyarakat dalam mendukung pihak Kepolisian dalam menjaga keamanan dan ketertiban di Labuhanbatu?

\subsection{Tujuan Penelitian}

Berdasarkan rumusan masalah diatas, maka yang menjadi tujuan penelitian ini adalah:

1. Untuk mengetahui dan menganalisis peranan Bhabinkamtibmas dalam menjaga keamanan dan ketertiban serta upaya penyelesaian sengketa melalui musyawarah di Labuhanbatu.

2. Untuk mengetahui dan menganalisis peranan masyarakat dalam mendukung pihak Kepolisian dalam menjaga keamanan dan ketertiban di Labuhanbatu.

\subsection{Manfaat Penelitian}

Kegiatan penelitian ini diharapkan dapat memberikan manfaat baik secara teoritis maupun pratis, yaitu:

\section{Secara Teoritis}

Menambah pengetahuan dan wawasan mengenai peraturan kepolisian dalam upaya menjaga ketertiban dan keamanan diwilayah hukum Polres Labuhanbatu. Penulis juga berharap dari hasil yang dirumuskan dalam penelitian ini dapat menjadi bahan bacaan ataupun literatur bagi pembaca yang tertarik dengan keberadaan Bhabinkamtibmas dan fungsi Bhabinkamtibmas dalam penyelesaian sengketa melalui musyawarah didalam masyarakat khususnya wilayah Labuhanbatu.

2. Secara Praktis

Menambah wawasan dan pengetahuan bagi kalangan masyarakat terhadap peran serta masyarakat dalam upaya menjaga ketertiban dan keamanan di Labuhanbatu dan peranan Bhabinkamtibmas di masyarakat.

\section{HASIL PENELITIAN DAN PEMBAHASAN}

2.1 Peran Bhabinkamtibmas dalam menjaga keamanan dan ketertiban serta upaya penyelesaian sengketa melalui musyawarah di Labuhanbatu

Keamanan dan ketertiban masyarakat (kamtibmas) adalah suatu usaha yang seharusnya diciptakan guna terpeliharanya kelangsungan kewibawaan pemerintah yang berkaitan erat dengan ketahanan nasional 
terlebih lagi negara saat ini dalam proses pembangunan, sehingga terciptanya kamtibmas yang mantap adalah salah satu unsur penting yang harus diciptakan demi berhasilnya pembangunan. Penyuluhan dan pendidikan hukum diberikan kepada masyarakat, secara garis besar berkaitan dengan faktor pelembagaan dan pengendapan hukum dalam masyarakat. Hal ini berarti, perlu adanya pengutamaan usaha-usaha yang mengarah kepada efektivitas dan evaluasi. Peningkatan kemampuan dan kewibawaan penegak hukum mengandung makna bahwa, para pelaku penegak hukum ialah orang-orang yang terlatih dan merasa terikat oleh hukum yang diterapkan serta seabagai pembuktian dalam pola kelakuan. Yang kemudian dapat dijadikan contoh teladan oleh faktor kepatuhan terhadap hukum

adapun tugas pokok, fungsi dan peranan bhabinkamtibmas adalah sebagai berikut :

\section{Tugas Pokok Bhabinkamtibmas}

Membina masyarakat agar tercipta kondisi yang menguntungkan bagi pelaksanaan tugas Polri di Desa/Kelurahan. Sesuai rumusan tugas pokoknya, maka lingkup tugas Bhabinkamtibmas meliputi :

a. melakukan pembinaan terhadap warga masyarakat yang menjadi tanggung jawabnya untuk dapat meningkatkan partisipasi masyarakat, kesadaran hukum dan ketaatan warga masyarakat terhadap hukum dan perundang- undangan yang berlaku;

b. melakukan upaya kegiatan kerjasama yang baik dan harmonis dengan aparat Desa, Tokoh Masyarakat, Tokoh Agama, Tokoh pemuda, Tokoh Adat dan para sepuh yang ada di Desa atau Kelurahan;

c. melakukan pendekatan dan membangun kepercayaan terhadap masyarakat ;

d. melakukan upaya pencegahan tumbuhnya penyakit masyarakat dan membantu penanganan rehabilitasi yang terganggu;

e. melakukan upaya peningkatan daya tangkal dan daya cegah warga masyarakat terhadap timbulnya gangguan Kamtibmas;

f. membimbing masyarakat untuk berpartisipasi aktif dalam rangka pembinaan Kamtibmas secara Swakarsa di Desa/Kelurahan;

g. melakukan kerjasama dan kemitraan dengan potensi masyarakat dan kelompok atau forum Kamtibmas guna mendorong peran sertanya dalam Binkamtibmas dan dapat mencari solusi dalam penanganan permasalahan atau potensi gangguan dan ambang gangguan yang terjadi dimasyarakat agar tidak berkembang menjadi gangguan nyata Kamtibmas;

h. menumbuhkan kesadaran dan ketaatan terhadap hukum dan perundangundangan;

i. memberikan bantuan dalam rangka penyelesaian perselisihan warga 
masyarakat yang dapat mengganggu

ketertiban umum;

j. memberikan petunjuk dan melatih masyarakat dalam rangka pengamanan lingkungan;

k. memberikan pelayanan terhadap kepentingan warga masyarakat untuk sementara waktu sebelum ditangani pihak yang berwenang.;

1. menghimpun informasi dan pendapat dari masyarakat untuk memperoleh masukan atas berbagai isu atau kisaran suara yang tentang penyelenggaraan fungsi dan tugas pelayanan Kepolisian serta permasalahan yang berkembang dalam masyarakat.

2. Fungsi Bhabinkamtibmas

a. membimbing dan menyuluh di bidang hukum dan Kamtibmas;

b. melayani masyarakat tentang hal-hal yang berkaitan dengan permasalahan Kamtibmas;

c. membina ketertiban masyarakat terhadap norma-norma yang berlaku;

d. memediasi dan memfasilitasi upaya pemecahan masalah yang terjadi di masyarakat;

e. mendinamisir aktifitas masyarakat yang bersifat positif;

f. mengkoordinasikan upaya pembinaan Kamtibmas dengan perangkat Desa/Kelurahan, Babinsa dan pihakpihak terkait lainnya.
3. Peran Bhabinkamtibmas

a. pembimbing masyarakat bagi terwujudnya kesadaran hukum, dan Kamtibmas serta meningkatkan partisipasi masyarakat di Desa/Kelurahan;

b. pelindung, pengayom, dan pelayan masyarakat bagi terwujudnya rasa aman dan tentram di masyarakat Desa/ Kelurahan;

c. mediator dan fasilitator dalam penyelesaian permasalahanpermasalahan sosial yang terjadi di masyarakat Desa/ Kelurahan;

d. dinamisator dan motivator aktivitas masyarakat yang bersifat positif dalam rangka menciptakan dan memelihara Kamtibmas.

Undang- Undang Nomor 2 Tahun 2002 tentang Kepolisian Negara Republik Indonesia mengatur tentang kewajiban, tugas, kewenangan dan hak-hak kepolisian, dimana dalam Pasal 2 fungsi Polri adalah menjaga keamanan dan ketertiban masyarakat (kamtibmas), peran Polri yang langsung berhubungan dengan masyarakat, Polri dianggap harus mampu bekerjasama dengan masyarakat guna menjaga ketertiban, ketentraman, dan norma yang berlaku dalam lingkungan masyarakat. Hal tersebut karena masyarakat juga mengharapkan norma tersebut dapat dipatuhi. Namun tidak semua masyarakat paham dan mau mematuhi norma yang mereka kehendaki sendiri, sehingga untuk itulah kedudukan Polri sebagai pelaku 
penegak hukum dapat mendorong terwujudnya kondisi yang aman dan tertib dalam masyarakat. Jadi selain untuk menjaga ketertiban dan keamanan pihak Kepolisian dalam hal ini juga mempunyai kewenangan dalam upaya pencegahan ketika terjadi sengketa di masyarakat tanpa harus membawa kejalur hukum atau membuat laporan ke kantor Kepolisian khususnya Polres Labuhanbatu.

Sesuai dengan landasan filosofis Negara Kesatuan Republik Indonesia adalah Pancasila yang merupakan dasar negara kita terutama sila keempat "Kerakyatan yang dipimpin oleh Hikmat Kebijaksanaan dalam Permusyawaratan / Perwakilan". Sila keempat dari Pancasila ini diantaranya menghendaki, bahwa upaya penyelesaian sengketa, konflik atau perkara dilakukan melalui musyawarah untuk mencapai mufakat yang diliputi oleh semangat kekeluargaan. Hal ini mengandung arti bahwa setiap sengketa, konflik atau perkara hendaknya diselesaikan melalui prosedur perundingan atau perdamaian di antara pihak yang bersengketa untuk memperoleh kesepakatan bersama. Semula mediasi di pengadilan cenderung bersifat fakultatif atau sukarela (voluntary), tetapi kini mengarah pada sifat imperative atau memaksa (compulsory). Peran Kepolisian bisa menjadi alternatif penyelesaian suatu sengketa untuk dilakukan dengan cara musyawarah agar tercapai perdamaian antara para pihak.

\subsection{Peranan Masyarakat Dalam} Mendukung Pihak Kepolisian
Dalam Menjaga Keamanan Dan Ketertiban Di Labuhanbatu

Berdasarkan SKEP KAPOLRI No: 373/X/2005 tertanggal 13 Oktober 2005 yang memerintahkan agar diberbagai tingkat organisasi Polri di bentuk Forum Kemitraan Polisi Masyarakat (FKPM) tujuan pembentukan FKPM ini untuk katimbas yang kondusif di wilayah desa / keluarahan dengan cara memberi pendapat dan saran kepada polri secara timbal balik agar terciptanya sinegritas antara Polri dengan masyarakat. Meningkatkan kesadaran dan kepatuhan hukum secara aktif membantu mencegah dan mengatasi tejadinya pelanggaran di wilayah kelurahan atau desa. Inti dari pembentukan Forum Kemitraan Polisi Masyarakat (FKPM) ini adalah untuk membantu tugas polri melalui polmas dalam membangun katibmas. Sehingga hal-hal yang muncul dan tergolong kecil bisa diselesaikan dengan kekeluargaan oleh Forum Kemitraan Polisi Masyarakat (FKPM) yang sudah ada di wilayah desa / kelurahan di Kabupaten Labuhanbatu, tidak harus dibawa ke kantor Polisi. Forum Kemitraan Polisi dan Masyarakat (FKPM) dalam mewujudkan kamtibmas tercantum dalam Undang- Undang No. 2 Tahun 2002 tentang Kepolisian Negara Republik Indonesia Pasal 2, 4, 14 Ayat (1), dan 15 Ayat (1). Berdasarkan Undang-Undang Polri tersebut diharapkan masyarakat juga turut serta dalam menyelenggarakan fungsi kepolisian dengan membantu Polri dalam menegakkan hukum 
dan menciptakan kamtibmas. Polri menetapkan berlakunya Polmas.

Masyarakat membantu Polri melalui Forum Kemitraan Polisi Masyarakat sebagai wadah dari Polmas itu sendiri. Polmas dan Forum Kemitraan Polisi dan Masyarakat diatur secara rinci dalam Peraturan Kapolri No. 3 Tahun 2015 tentang Pemolisian Masyarakat, yaitu Pasal 1 angka (2). Berdasarkan ketentuan Pasal 1 angka (2) Peraturan Kapolri No. 3 Tahun 2015 tentang Pemolisian Masyarakat maka dapat peneliti kemukakan bahwa dengan adanya kemitraan antara polisi dan masyarakat dapat mendeteksi dan mengidentifikasi permasalahan serta menyelesaikan masalah tersebut, sehingga dapat dikatakan bahwa masyarakat sebagai ujung tombak dari hukum dalam bertindak membantu polisi melalui wadah Forum Kemitraan Polisi dan Masyarakat.

Berdasarkan Pasal 5 Perkap Nomor 3 Tahun 2015 fungsi Polmas tentang Pemolisian Masyarakat :

a. Mengajak masyarakat melalui kemitraan dalam rangka pemeliharaan kamtibmas.

b. Membantu masyarakat mengatasi masalah sosial dilingkunganya dalam rangka mencegah terjadinya gangguan kamtibmas.

c. Mendeteksi, mengidentifikasi, menganalisis, menetapkan prioritas masalah, dan merumuskan pemecahan masalah kamtibmas; dan d. Bersama masyarakat menerapkan hasil pemecahan masalah kamtibmas.

\section{KESIMPULAN}

Berdasarkan pembahasan yang telah dikemukakan penulis sebelumnya maka dapat diambil kesimpulan sebagai berikut:

1. Dalam Undang- Undang Nomor 2 Tahun 2002 tentang Kepolisian Negara Republik Indonesia mengatur tentang kewajiban, tugas, kewenangan dan hak-hak kepolisian, dimana dalam Pasal 2 fungsi Polri adalah menjaga keamanan dan ketertiban masyarakat (kamtibmas), peran Polri yang langsung berhubungan dengan masyarakat, Polri dianggap harus mampu bekerjasama dengan masyarakat guna menjaga ketertiban, ketentraman, dan norma yang berlaku dalam lingkungan masyarakat. untuk itulah kedudukan Polri sebagai pelaku penegak hukum dapat mendorong terwujudnya kondisi yang aman dan tertib dalam masyarakat. Jadi selain untuk menjaga ketertiban dan keamanan pihak Kepolisian dalam hal ini juga mempunyai kewenangan dalam upaya pencegahan ketika terjadi sengketa di masyarakat tanpa harus membawa kejalur hukum atau membuat laporan ke kantor Kepolisian khususnya Polres Labuhanbatu.

2. Peranan masyarakat untuk mendukung Kepolisian dalam manjaga keamanan dan ketertiban pada wilayah hukum Polres 
Labuhanbatu sejalan dengan Peran dari

Forum Kemitraan Polisi Masyarakat (FKPM) untuk menjaga katimbas yang kondusif di wilayah khususnya di Labuhanbatu dengan cara memberi pendapat dan saran kepada Kepolisian secara timbal balik. Meningkatkan kesadaran dan kepatuhan hukum secara aktif membantu mencegah dan mengatasi tejadinya pelanggaran di wilayah kelurahan atau desa. Inti dari pembentukan Forum Kemitraan Polisi Masyarakat (FKPM) ini adalah untuk membantu tugas Kepolisian melalui polmas dalam membangun katibmas. Sehingga hal-hal yang muncul dan tergolong kecil bisa diselesaikan dengan kekeluargaan oleh Forum Kemitraan Polisi Masyarakat (FKPM), tidak harus dibawa ke kantor Polisi di wilayah hukum Polres Labuhanbatu.

\section{DAFTRAR PUSTAKA}

\section{a. Buku}

Untung S. Rajab. 2003. Kedudukan dan Fungsi Polisi Republik Indonesia Dalam Sistem Ketatanegaraan (berdasarkan UUD 1945). Bandung: Cv. Utomo.

Pudi Rahardi. 2007. Hukum Kepolisian. Surabaya : Laksbang Mediatama.

Frans Hendra Winarta. 2012. Hukum Penyelesaian Sengketa. Jakarta: Sinar Grafika.
Hamzah Baharudin dan Masaluddin. 2010. Kontruktivisme Kepolisian. Makasar: Pustaka Refleksi.

Wahyono. 2011. "Dinamika Fungsi Kepolisian Dan Hubungannya Dengan Program Perpolisian Masyarakat". Perspektif. Volume XVI No. 3 Tahun 2011 Edisi Mei.

\section{b. Perundang -undangan}

Undang-Undang Nomor 2 Tahun 2002 tentang Kepolisian Negara Republik Indonesia

Peraturan Kapolri No. 3 Tahun 2015 tentang Pemolisian Masyarakat 